\title{
Article \\ Investigation of UV Dye-Sensitized Solar Cells Based on Water Electrolyte: A New Insight for Wavelength-Selective Greenhouse
}

\author{
Daiana Albulescu 1,2, Daniel Ursu 1미 , Lucian-Mircea Rusnac ${ }^{2}$, Sabina Nitu ${ }^{2}$, Marinela Miclau ${ }^{1}$ \\ and Melinda Vajda ${ }^{1,2, *}$ \\ 1 National Institute for Research and Development in Electrochemistry and Condensed Matter, \\ 300569 Timisoara, Romania; daiana.albulescu@student.upt.ro (D.A.); danielhoratiu@yahoo.com (D.U.); \\ marinela.miclau@gmail.com (M.M.) \\ 2 Faculty of Industrial Chemistry and Environmental Engineering, Politehnica University Timisoara, \\ 300006 Timisoara, Romania; lucian.rusnac@upt.ro (L.-M.R.); sabina.nitu@upt.ro (S.N.) \\ * Correspondence: melinda.vajda@student.upt.ro
}

Citation: Albulescu, D.; Ursu, D.; Rusnac, L.-M.; Nitu, S.; Miclau, M.; Vajda, M. Investigation of UV Dye-Sensitized Solar Cells Based on Water Electrolyte: A New Insight for Wavelength-Selective Greenhouse. Crystals 2022, 12, 98. https:/ / doi.org/10.3390/ cryst12010098

Academic Editor: Guanying Chen

Received: 10 December 2021

Accepted: 10 January 2022

Published: 13 January 2022

Publisher's Note: MDPI stays neutral with regard to jurisdictional claims in published maps and institutional affiliations.

Copyright: (C) 2022 by the authors. Licensee MDPI, Basel, Switzerland. This article is an open access article distributed under the terms and conditions of the Creative Commons Attribution (CC BY) license (https:// creativecommons.org/licenses/by/ $4.0 /)$.

\begin{abstract}
The optimization of the photoactive electrode based on $\mathrm{TiO}_{2}$ with a complex architecture for UV dyes along with water-based electrolyte has successfully allowed us (i) to obtain a photovoltaic efficiency of the dye-sensitized solar cell with 1.45 times higher than the best efficiency reported for synthetic dye and 3 times for curcumin dye so far; (ii) transparency on the entire Photosynthetic Active Radiation domain; (iii) preserving high efficiency for lighting 1 sun (summer) and shading, especially for $60 \mathrm{~mW} / \mathrm{cm}^{2}$, which represents the maximum illumination in the rest of the seasons. Our water-based dye-sensitized solar cells loaded with synthetic and natural UV dyes have revealed that the implementation of a dye-sensitized solar cell in autonomous greenhouses is a viable and inexpensive concept.
\end{abstract}

Keywords: dye-sensitized solar cell; wavelength-selective greenhouse; UV natural dye; UV synthetic dye

\section{Introduction}

In the context of the expected energy and food crisis, medium- and long-term forecasts have highlighted the need for finding synergetic solutions. An agrivoltaic system is proposed as a possible option that combines agriculture and the generation of photovoltaic energy, alleviating land competition or other spatial restrictions for energy production. A photovoltaic greenhouse must strike a balance between two complementary requirements: (i) maximizing the flow of Photosynthetic Active Radiation (PAR), the light of wavelengths between 430 and $700 \mathrm{~nm}$, which is essential for the growth and photosynthesis of plants, by reducing the shading effect of photovoltaic panels [1], and (ii) further enhancement of the production of energy that will ensure the energetic autonomy of the greenhouse.

The theoretically predicted power conversion efficiency (PCE) of the dye-sensitized solar cell (DSSC) is approximately 20\% [2], and in the last few decades, a lot of experiments have focused on continuing increasing the efficiency compared with the used Si-based solar cell, as well as the large modules installations for terrestrial power generation. In recent years, this limited objective has been extended to the advantages over the widely used Si-based solar cell, including higher energy conversion efficiency under weak and indirect illumination conditions. These advantages can compensate for the weaknesses of $\mathrm{Si}$ based solar cells and together with the simple manufacturing process, low fabrication cost, flexibility in scaling, low material usage [3-5], and low light level sensitivity, but mainly the variation in color and transparency of the photoanode together with that of the counter electrode [6,7], are essential characteristics that could make these cells the ideal candidate for greenhouse application $[8,9]$. 
The selection of the color of DSSC given by the dye can act as a plant growth regulator or serve as a photo selective covering adsorbed with dye to manipulate the light spectrum entering the greenhouse. Thus, this technology could deliver impressive benefits in contrast to conventional photovoltaic panels (the first and second generations of the solar cells) because of its solar radiation manipulation through the optimum choice of photosensitizer.

Making more efficient photoelectrodes is one of the key factors needed for the increased performance of DSSCs, being responsible for the dye loading capacity and the transfer pathway of electrons. For this, several strategies for the $\mathrm{TiO}_{2}$ photoanode improvement were proposed, including the overlayer of $\mathrm{TiO}_{2}$ substrate with CdSe particles for a better electron transfer [10], the Ag doping of the $\mathrm{TiO}_{2}$ material leading to a visible increase in $J_{S C}$ [11], and a polymer interlayer $\mathrm{TiO}_{2}$-based DSSC for the prevention of charge recombination and to facilitate the ionic conduction [12].

Our paper aims to propose and experimentally demonstrate an architecture of DSSC which shall be respected simultaneously: (i) partial absorption of solar UV radiation with a positive impact on plant growth and reduced plant pathogenicity [13]; (ii) transparency throughout the PAR domain; (iii) water-based electrolytes, ensuring the realization of safe, less expensive, and environmentally friendly solar cells [14]; and (iv) improvement of the energy performance of DSSC based on UV dyes for full sun and shading conditions. Each of the above requirements has been successfully fulfilled, namely: (i) an affordable commercial dye (DN-F01) and a natural curcumin dye that absorbs UV radiation; (ii) introduction of the water in a low-cost common electrolyte; (iii) design and optimization of the photoactive electrode based on the $\mathrm{TiO}_{2}$ polymorphs for these dyes and water-based electrolyte; (iv) improving the energy performance of DSSC based on synthetic and natural UV dyes for full sun and shading conditions, without affecting PAR.

Thus, the photoactive $\mathrm{TiO}_{2}$-based electrode with complex architecture was successfully optimized for UV dyes sensitization and tested using water-based electrolyte, yielding a photovoltaic efficiency 1.45 and 3 times higher than the best efficiency reported for synthetic and curcumin dye so far $[15,16]$. With a maximum of efficiency under $60 \mathrm{~mW} / \mathrm{cm}^{2}$ of illumination, excellent performance even under conditions of not optimal lighting was obtained.

\section{Materials and Methods}

\subsection{Preparation of $\mathrm{TiO}_{2}$ Nanoparticles $\left(\mathrm{TiO}_{2} \mathrm{NP}\right)$}

An amount of $2.13 \mathrm{~mL}$ of titanium (IV) isopropoxide (Sigma-Aldrich Co., Merck KGaA, Darmstadt, Germany) was added at room temperature and continuously stirred into a solution formed from $1 \mathrm{~g}$ of Pluronic P123 (Sigma-Aldrich) dissolved in $10 \mathrm{~mL}$ of isopropyl alcohol. The prepared solution was stirred for $3 \mathrm{~h}$ at $350 \mathrm{rpm}$, and after left to age for $24 \mathrm{~h}$, until a solid gel was formed. The as obtained gel was then dried at $60{ }^{\circ} \mathrm{C}$ for $24 \mathrm{~h}$ and further sintered at $450{ }^{\circ} \mathrm{C}$ for $1 \mathrm{~h}$, to obtain the white $\mathrm{TiO}_{2}$ particles.

\subsection{Preparation of $\mathrm{TiO}_{2}$ Particles for Light Scattering $\left(\mathrm{TiO}_{2} \_L S\right)$}

In the first step, $\mathrm{TiO}_{2} \mathrm{LS} 1$ were obtained by dissolving $5 \mathrm{~mL}$ of titanium (III) chloride solution (Sigma-Aldrich Co., Merck KGaA, Darmstadt, Germany) in $30 \mathrm{~mL}$ of water and stirred for $10 \mathrm{~min}$ at room temperature. $6 \mathrm{~mL}$ of supersaturated $\mathrm{NaCl}$ solution was then added to the previously prepared mixture and stirred for another $10 \mathrm{~min}$. The resulting mixture was transferred to a $50 \%$ filled Teflon-lined autoclave and heated at $160{ }^{\circ} \mathrm{C}$ for $2 \mathrm{~h}$. After the hydrothermal treatment a white precipitate was obtained, which was washed several times by centrifugation at $8000 \mathrm{rpm}$ with $\mathrm{Dl}$ water and ethanol and air-dried at $30{ }^{\circ} \mathrm{C}$ for $24 \mathrm{~h}$.

For the formation of nanosheet aggregates, another step of hydrothermal treatment was applied to a mixture consisting of $0.1 \mathrm{~g}$ of a previously made $\mathrm{TiO}_{2} \mathrm{LS} 1$ precursor, and added into a solution of $5 \mathrm{M} \mathrm{NaOH}$, at $140{ }^{\circ} \mathrm{C}$ for $24 \mathrm{~h}$. The resulting white sediment was washed by filtration with a $0.1 \mathrm{M} \mathrm{HCl}$ solution until an acidic $\mathrm{pH}$ of the rinse solution 
was obtained and further sintered at $400{ }^{\circ} \mathrm{C}$ for $30 \mathrm{~min}$, to obtain the $\mathrm{TiO}_{2}$ nanosheet aggregates $\left(\mathrm{TiO}_{2} \_\mathrm{LS} 2\right)$ for light scattering.

The phase purity and crystal structure of the as-obtained powders were characterized by X-ray diffraction (XRD), using the PANalytical PW 3040/60 X'Pert PRO diffractometer (Malvern Panalytical, Malvern, United Kingdom), with a $1.5418 \AA$ A wavelength of the Cu$\mathrm{K} \alpha$ radiation, in the range $2 \theta=10-80^{\circ}$. Surface morphology was analyzed with the FEI Inspect $S$ scanning electron microscope (SEM, FEI Company, Eindhoven, The Netherlands). A Lambda 950 UV-Vis-NIR (PerkinElmer, Waltham, CT, USA) spectrophotometer with a $150 \mathrm{~mm}$ integrating sphere was used to collect the diffuse reflectance spectra (DSR) in the wavelength range of 300-800 $\mathrm{nm}$ at room temperature, and the optical band gap of the oxide powders was estimated. The FTIR spectra were collected in the $4000-400 \mathrm{~cm}^{-1}$ range, with a JASCO-430 (Jasco Co., Tokyo, Japan) Fourier transform spectrometer and by using the $\mathrm{KBr}$ pellet technique.

\subsection{Preparation of Curcumin Dye}

To obtain the curcumin dye, $4 \mathrm{~g}$ of turmeric powder was dissolved in $200 \mathrm{~mL}$ of ethyl acetate by magnetic stirring for $1 \mathrm{~h}$ at $40^{\circ} \mathrm{C}$. The extract was then filtered on filter paper three times to remove any solid particles. The concentration of the curcumin extract was made using a Heidolph Rotary Evaporator-Laborota 4000 (Heidolph Instruments, Schwabach, Germany), at a pressure of $160 \mathrm{mbar}$ and a bath temperature of $40^{\circ} \mathrm{C}$. An amount of $40 \mathrm{~mL}$ of the concentrated natural curcumin dye was obtained and used as a photosensitizer in DSSC. The extraction of the natural dye from turmeric powder is described in Figure 1.

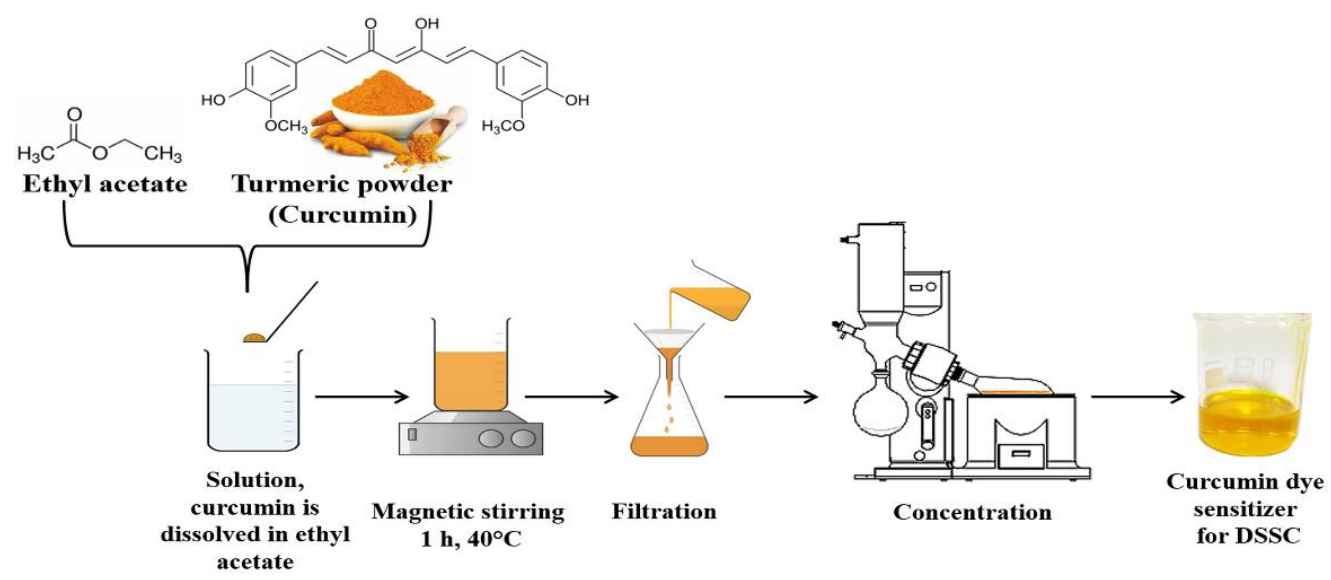

Figure 1. The Curcumin dye extraction process.

The absorbance spectrum was collected using a Lambda 950 UV-Vis-NIR (PerkinElmer, Waltham, CT, USA) spectrophotometer in the wavelength range of $250-800 \mathrm{~nm}$ at ambient temperature.

\subsection{Fabrication of DSSCS}

$\mathrm{TiO}_{2} \mathrm{NP}$ and $\mathrm{TiO}_{2}$ LS pastes were prepared as in our previous study [17] using ethyl cellulose, $\alpha$-terpineol, glacial acetic acid, and $\mathrm{Dl}$ water as paste constituents.

For the optimized photoanode realization, multiple layers of paste were deposited using the doctor blade technique on the previously cleaned and UV-Ozone-treated FTO glass substrate (Sigma Aldrich, with a surface resistivity of $\sim 13 \Omega \mathrm{sq}^{-1}$ ). First, a $\mathrm{TiO}_{2} \mathrm{NP}$ layer was deposited, followed by 2 layers of $\mathrm{TiO}_{2} \mathrm{LS}\left(\mathrm{TiO}_{2} \mathrm{LS} 1\right.$ or $\left.\mathrm{TiO}_{2} \mathrm{LS} 2\right)$, after each deposited layer, a sintering process was applied at a temperature of $500{ }^{\circ} \mathrm{C}$ for $1 \mathrm{~h}$ with a $1{ }^{\circ} \mathrm{C} \mathrm{min}-1$ heating rate. Finally, the double-layered paste configuration was immersed in a $40 \mathrm{mM} \mathrm{TiCl}$ solution at $70{ }^{\circ} \mathrm{C}$ for $1 \mathrm{~h}$ and sintered at $450{ }^{\circ} \mathrm{C}$ for $1 \mathrm{~h}$ with a $1{ }^{\circ} \mathrm{C} \mathrm{min}-1$ heating rate.

The optimized configuration was determined by testing different photoanodes prepared with different functionalized layers. Photoanode 1 ( $\mathrm{PhA} 1$ ) consists of a single layer 
of $\mathrm{TiO}_{2} \_\mathrm{NP}$, photoanode 2 ( $\mathrm{PhA}$ 2) consists of $\mathrm{TiO}_{2} \_\mathrm{NP}$ and $\mathrm{TiO}_{2} \_\mathrm{LS} 1$ layers, photoanode 3 (PhA 3) consists of $\mathrm{TiO}_{2} \_\mathrm{NP}$ and $\mathrm{TiO}_{2}$ LS2 layers, and photoanode 4 ( $\mathrm{PhA} 4$ ) consists of a $\mathrm{TiO}_{2}$ NP layer, a $\mathrm{TiO}_{2} \_\mathrm{LS} 2$ layer, and $\mathrm{TiCl}_{4}$ treatment. For a better understanding of the layer configuration, a schematic representation is presented in Figure 2.

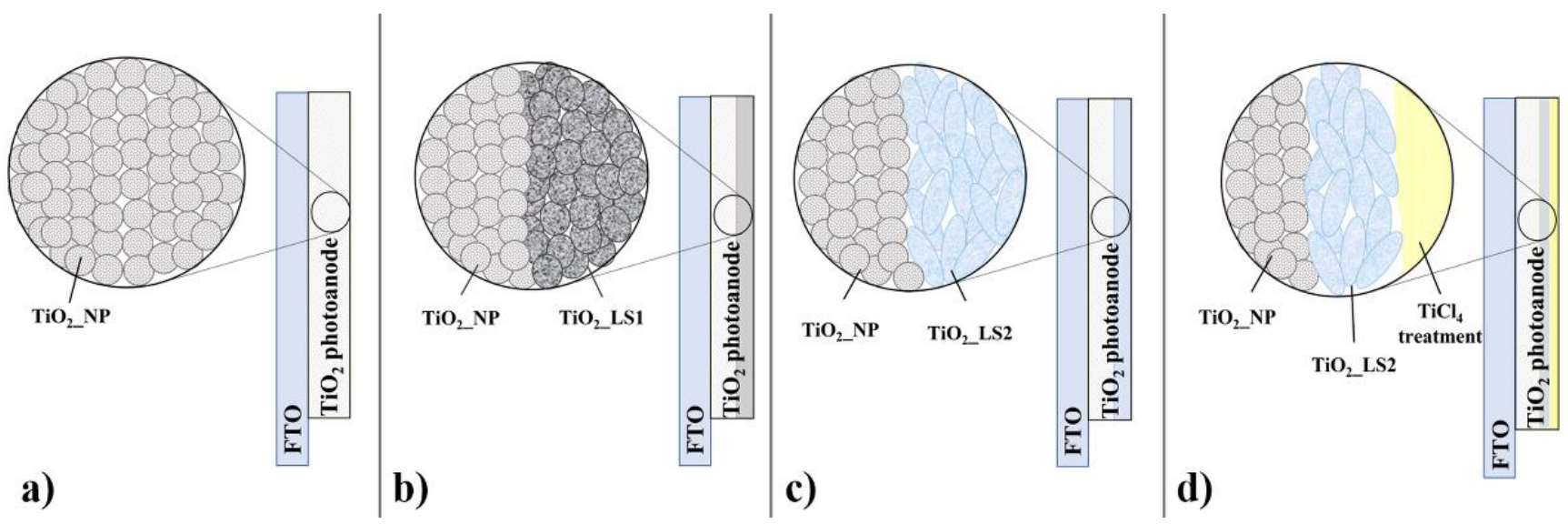

Figure 2. Schematic representation of the layer configuration in (a) PhA 1, (b) PhA 2, (c) PhA 3 , and (d) PhA 4 photoanodes.

Two dyes were used for the sensitization of the photoanodes, a synthetic dye consisting of a $0.3 \mathrm{mM}$ solution of DN-F01 (Dyenamo Yellow) in absolute ethanol ( $5 \mathrm{~h}$ immersion time) and a natural curcumin extract ( $1 \mathrm{~h}$ immersion time). The obtained sensitized photoanodes were fixed together with the counter electrodes produced by treating a $\mathrm{H}_{2} \mathrm{PtCl}_{6}$ solution at $400{ }^{\circ} \mathrm{C}$, using a Meltonix 1170-60 thick spacer.

The electrolyte used and injected into the space between the electrodes consists of a solution of 0.6M 1-butyl-3-methyl-immidazolium iodide, $0.03 \mathrm{M} \mathrm{I}_{2}, 0.10 \mathrm{M}$ guanidinium thiocyanate and 0.5 M 4-tertbutylpyridine in acetonitrile/valeronitrile (85:15, v/v), hereinafter referred to as E. The water effect on the DSSC performance was also studied by replacing $10 \%$ of the solvent medium in the E electrolyte with water, named E10\%.

The DSSCs produced based on the photoanodes will henceforth be called DSSC 1, DSSC 2, DSSC 3, and DSSC 4, respectively.

For determining the photovoltaic performances of the DSSCs, the photocurrent density vs. photovoltage curves were recorded on a Keithley 2450 source measure unit, keeping a scan rate equal to $1 \mathrm{mV}$ and under different illumination conditions (20-100 $\mathrm{mW} \mathrm{cm}^{-2}$ ). Electrochemical impedance spectroscopy (EIS) measurements were performed using a Voltalab potentiostat model PGZ 402, with VoltaMaster 4 software (version 7.09), under different illumination conditions and a frequency range from 0.001 to $10 \mathrm{kHz}$, using $10 \mathrm{mV}$ of the magnitude for the modulation signal. The applied potentials were taken as the $V_{O C}$ values determined for the DSSC4 configuration tested with and without water content in the electrolyte, at two illumination intensities $\left(60\right.$ and $\left.100 \mathrm{~mW} \mathrm{~cm}^{-2}\right)$, and by using both dyes' sensitization (synthetic and natural).

\section{Results}

The XRD pattern of the $\mathrm{TiO}_{2}$ nanoparticles obtained by a simple sol-gel procedure is shown in Figure 3a. All diffraction peaks are indexed as $\mathrm{TiO}_{2}$ crystallized in anatase form, having a tetragonal structure (space group: I41/amd; JCPDS No. 01-073-1764). No other $\mathrm{TiO}_{2}$ crystalline phases such as rutile or brookite can be observed. The XRD patterns of the obtained microparticles used as scattering layers in the DSSC configurations are presented in Figure 3b,c. In the case of the $\mathrm{TiO}_{2}$ LS1 sample, a crystallization in rutile form with the tetragonal structure of the $\mathrm{TiO}_{2}$ can be observed (space group: P42/mnm; JCPDS No. 00-021-1276). Furthermore, a mixture of polymorphic phases of $\sim 46 \%$ rutile and $\sim 54 \%$ anatase was obtained in the $\mathrm{TiO}_{2} \_\mathrm{LS} 2$ sample. 


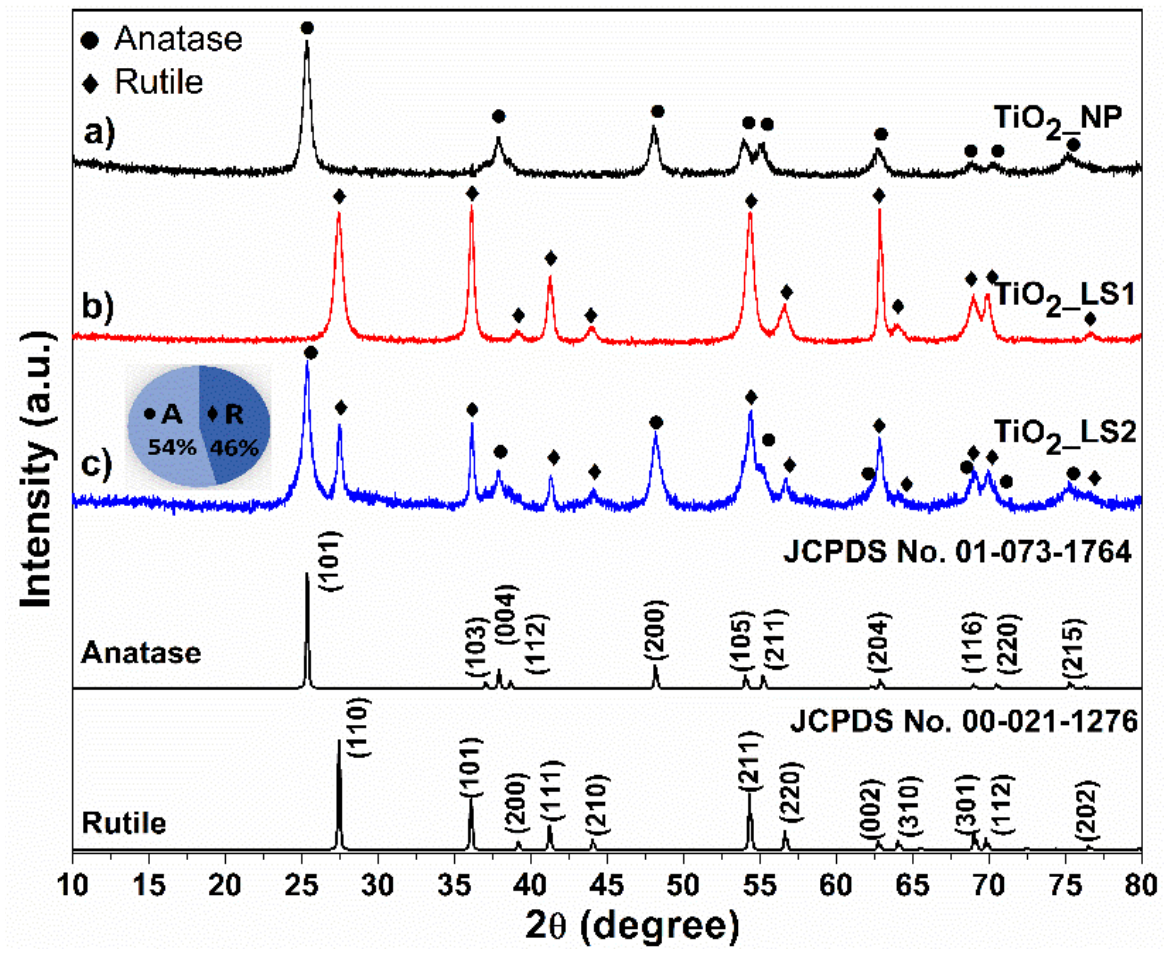

Figure 3. X-ray diffraction pattern of (a) $\mathrm{TiO}_{2} \_\mathrm{NP}$, (b) $\mathrm{TiO}_{2} \_\mathrm{LS} 1$, and (c) $\mathrm{TiO}_{2} \_\mathrm{LS} 2$ obtained at room temperature.

The crystallite sizes of the obtained $\mathrm{TiO}_{2}$ powders were calculated using the Scherrer formula [18]:

$$
D_{h k l}=\frac{k \lambda}{B \cos \theta}
$$

where $k$ is a constant $(\sim 1), B$ is the full width at half maximum (FWHM), $\lambda$ the wavelength of the $X$-ray and $\theta$ is the diffraction angle. The obtained crystallite sizes were of $\sim 15 \mathrm{~nm}$ for the $\mathrm{TiO}_{2} \_\mathrm{NP}$ sample, of $\sim 25 \mathrm{~nm}$ for the $\mathrm{TiO}_{2} \mathrm{LS} 1$ sample, and of $\sim 33 \mathrm{~nm}$ and $\sim 23 \mathrm{~nm}$ for the anatase and rutile phases of the $\mathrm{TiO}_{2} \mathrm{LS} 2$ sample, respectively.

Figure 4 presents the SEM images of the two architectures proposed for the light scattering effect, $\mathrm{TiO}_{2} \mathrm{LS} 1$ showing a solid microsphere structure, and a dendritic structure containing agglomerated nanorods was obtained for the $\mathrm{TiO}_{2} \mathrm{LS} 2$ sample.
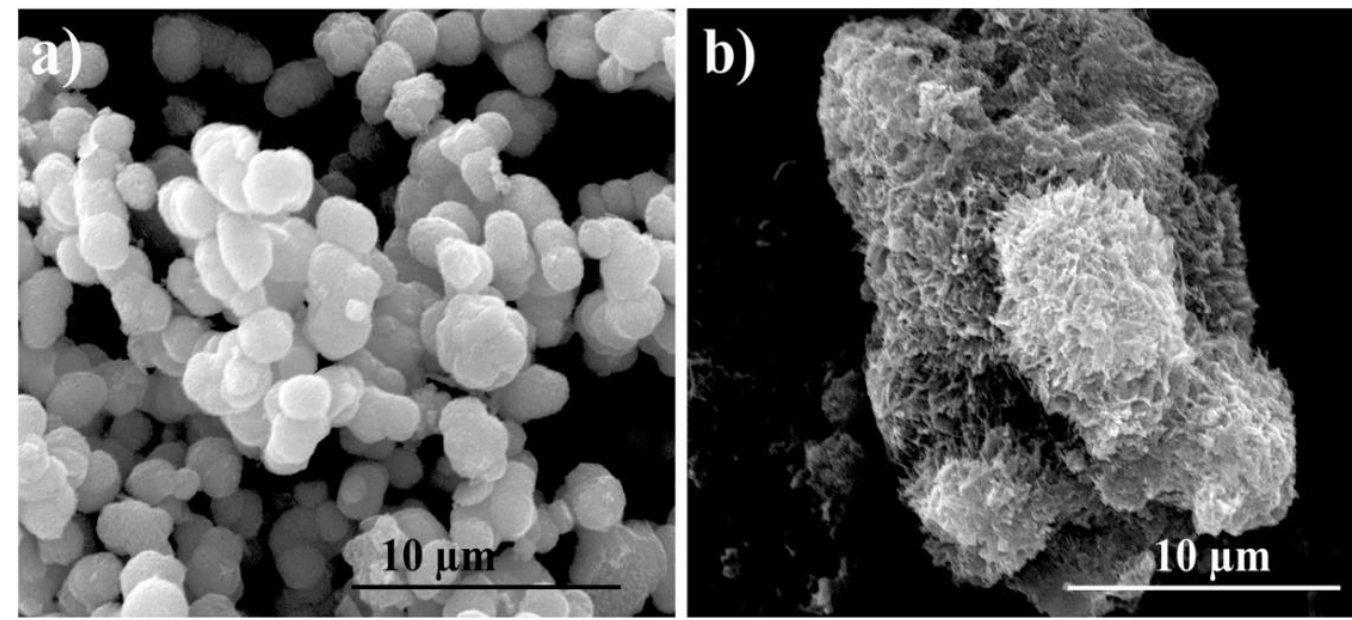

Figure 4. SEM images of the (a) $\mathrm{TiO}_{2} \_\mathrm{SL} 1$ and (b) $\mathrm{TiO}_{2} \_\mathrm{SL} 2$ structures proposed for a scattering effect. 
The FT-IR spectra of the samples measured in the range of $4000-400 \mathrm{~cm}^{-1}$ are presented in Figure 5. The first two peaks observed at 3438 and $1630 \mathrm{~cm}^{-1}$ correspond to the stretching vibrations of the hydroxyl group $\mathrm{O}-\mathrm{H}$ of interlayer water molecules and the bending mode of water molecules $\delta\left(\mathrm{H}_{2} \mathrm{O}\right)$, respectively [19]. The broad and intense band between $881 \mathrm{~cm}^{-1}$ and $408 \mathrm{~cm}^{-1}$ with maximum at $481 \mathrm{~cm}^{-1}$ assigned to Ti-O and Ti-O-Ti stretching and bending vibrations is characteristic of the pure anatase polymorph of $\mathrm{TiO}_{2}$ [20]. In case of $\mathrm{TiO}_{2} \_\mathrm{LS1}$, the intense band in the range of $881-452 \mathrm{~cm}^{-1}$ with a maximum at $620 \mathrm{~cm}^{-1}$ is attributed to the Ti-O vibration of pure rutile [21]. In accordance with the XRD pattern of $\mathrm{TiO}_{2}$ LS2, the band widening is extended in the range $1025-408 \mathrm{~cm}^{-1}$ with two specific maxima for both anatase and rutile polymorphs. The high $\mathrm{NaOH}$ molarity used in $\mathrm{TiO}_{2} \mathrm{LS}_{2}$ preparation caused the formation of surface hydroperoxo species, $\mathrm{TiOOH}$, that exhibits an absorption band at $970 \mathrm{~cm}^{-1}$ due to vibration modes [22].

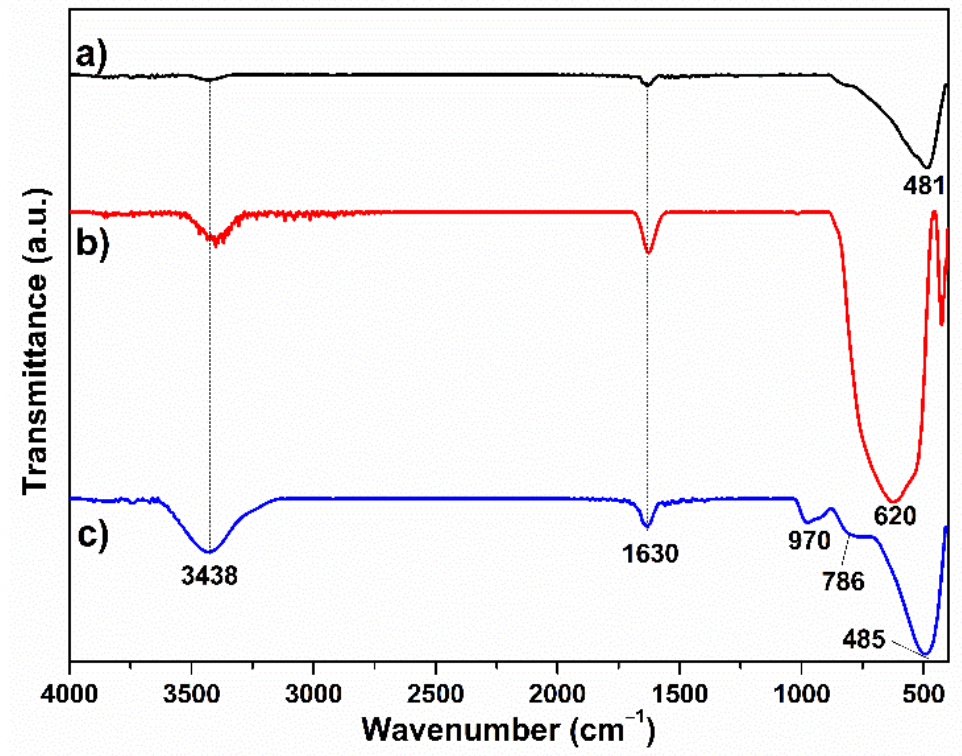

Figure 5. FTIR spectra of (a) $\mathrm{TiO}_{2} \_\mathrm{NP},(\mathbf{b}) \mathrm{TiO}_{2} \_\mathrm{LS} 1$, and (c) $\mathrm{TiO}_{2} \_\mathrm{LS} 2$.

From the diffuse reflectance spectra, presented in Figure 6, the optical direct band gaps of the $\mathrm{TiO}_{2}$ photoelectrode materials were estimated by using the Tauc plot [23], and intercepting the extrapolated linear fit for the plotted experimental data of $(\alpha \mathrm{h} v)^{2}$ versus incident photon energy ( $\mathrm{h} v$ ) near the absorption edge. The obtained values of $3.12 \mathrm{eV}$ and $3.09 \mathrm{eV}$ for $\mathrm{TiO}_{2} \_\mathrm{NP}$ and $\mathrm{TiO}_{2} \mathrm{LS} 1$, respectively, are comparable to the data reported in the literature for anatase and rutile polymorphs of $\mathrm{TiO}_{2}$ structures [24]. The value of $3.36 \mathrm{eV}$ obtained for the $\mathrm{TiO}_{2}$ LS2 sample is much higher than previously reported values of mixed anatase-rutile $\mathrm{TiO}_{2}$ nanoparticles [25]. In general, the value of Eg of a mixed $\mathrm{TiO}_{2}$ nanoparticles with rutile and anatase structures decreases continuously with the increase in rutile content. In the case of $\mathrm{TiO}_{2} \_\mathrm{LS} 2$, a significant increase in the band gap was highlighted and could be correlated with the presence of the surface titanium hydroperoxo species revelated by FTIR spectra.

The UV-Vis spectrum of curcumin in ethyl acetate solution showed a broad absorption at around 300-450 $\mathrm{nm}$ with a maximum absorption band at a wavelength of $416 \mathrm{~nm}$ attributed to the electronic transitions $\mathrm{n} \rightarrow \pi^{*}$, and a weak absorption band at $251 \mathrm{~nm}$ to the electronic transitions $\pi \rightarrow \pi^{*}$, respectively. The groups responsible for the absorption of the dye are the carbonyl groups in the structure of curcumin and the accumulation of groups grafted on the aromatic nucleus producing a bathochrome shift. The DN-F01 dye is similarly characterized by a broad absorption at around $350-480 \mathrm{~nm}$ with a maximum absorption band at a wavelength of $421 \mathrm{~nm}$ (Figure 7). 


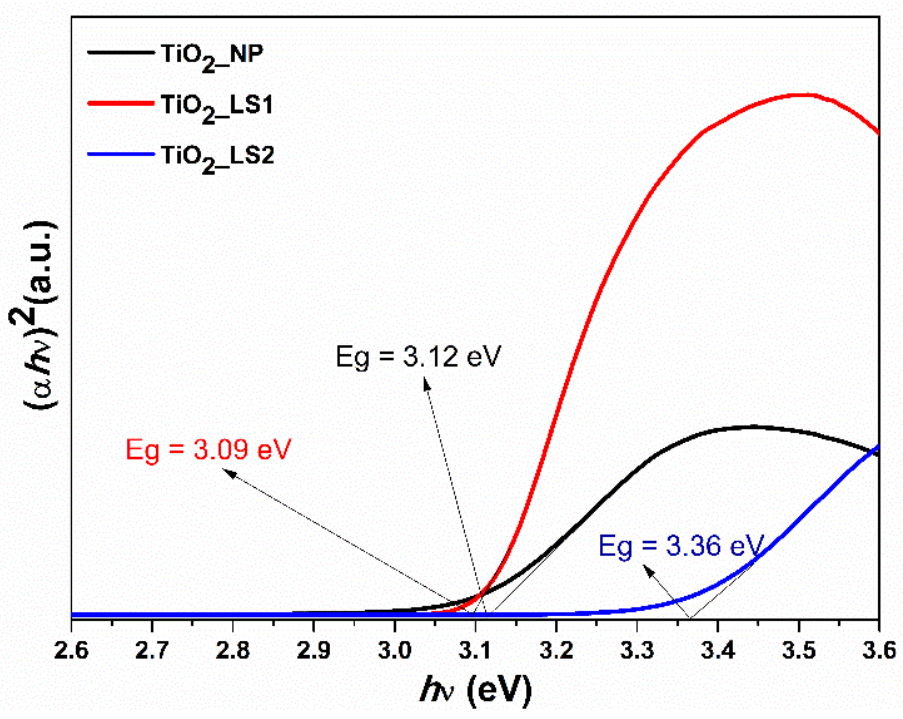

Figure 6. Band gaps of $\mathrm{TiO}_{2} \_\mathrm{NP}, \mathrm{TiO}_{2} \_\mathrm{LS} 1$, and $\mathrm{TiO}_{2}$ LS2 photoelectrode materials calculated from the diffuse reflectance spectra.
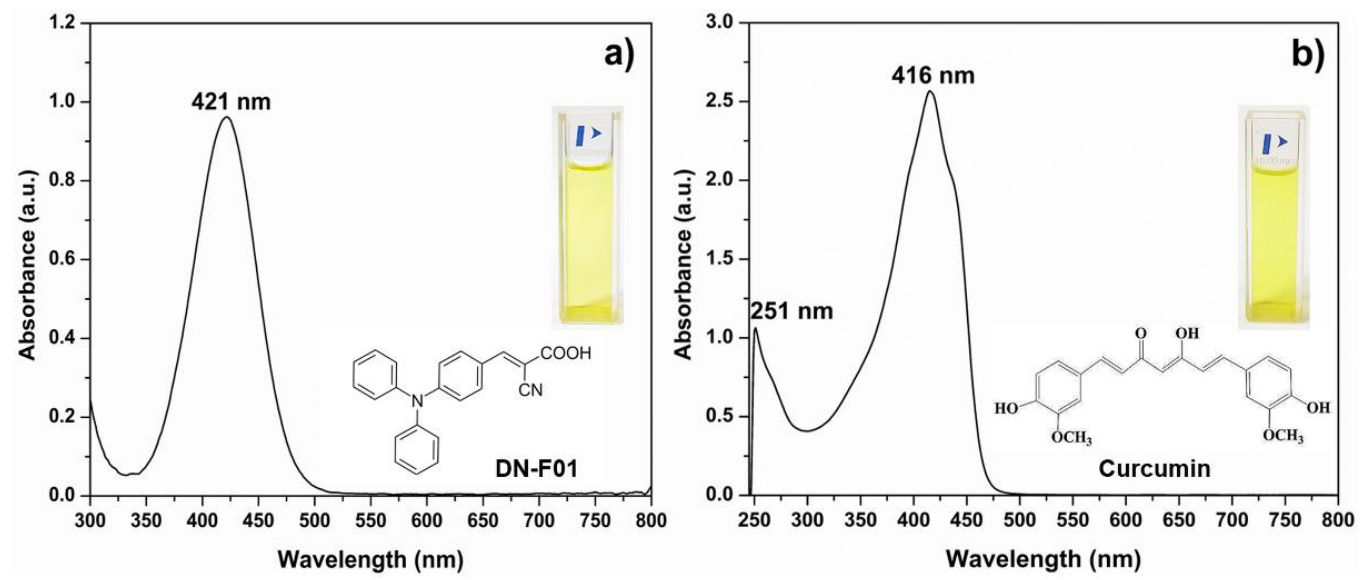

Figure 7. UV-Vis absorption spectra of (a) DN-F01 dye and (b) curcumin dye in ethyl acetate.

The successful implementation of DSSC in an energetically independent greenhouse is conditioned by four main requirements, namely eco-friendly materials, transparency in the entire PAR domain, high UV absorption, good photovoltaic efficiency, and sustainability throughout the year. To simultaneously fulfil the above-mentioned objectives, four different architectures of $\mathrm{TiO}_{2}$ photoactive electrodes (PhA 1, PhA 2, PhA 3, and PhA 4) using synthetic and natural dyes, and water-based electrolytes were designed and tested.

From the SEM images presented in Figure $8 \mathrm{a}-\mathrm{d}$, the uniformity and surface morphology of the as-deposited $\mathrm{TiO}_{2}$ thin films can be observed. As can be seen, the particle morphologies were preserved during the paste formation, deposition, and thermal treatment of photoanodes.

To investigate the light scattering effect of the $\mathrm{TiO}_{2}$ particles synthesized for this purpose, the reflectance spectra of all photoelectrode configurations were studied (Figure 9). A higher reflectance for the PhA 2, PhA 3, and PhA 4 photoelectrodes in the wavelength range of 400-800 can be observed compared with that of the $\mathrm{TiO}_{2} \mathrm{NP}$ particle film (PhA 1), confirming that spherical $\mathrm{TiO}_{2}$ aggregate films have a higher light scattering capacity, due to their larger diameters, which are comparable to the wavelengths of visible light. The distance traveled by the incident light within the photoelectrode is significantly extended by the better scattering effect, with this increasing the photon harvesting by the dye molecules and leading to a relatively higher photocurrent [26]. 

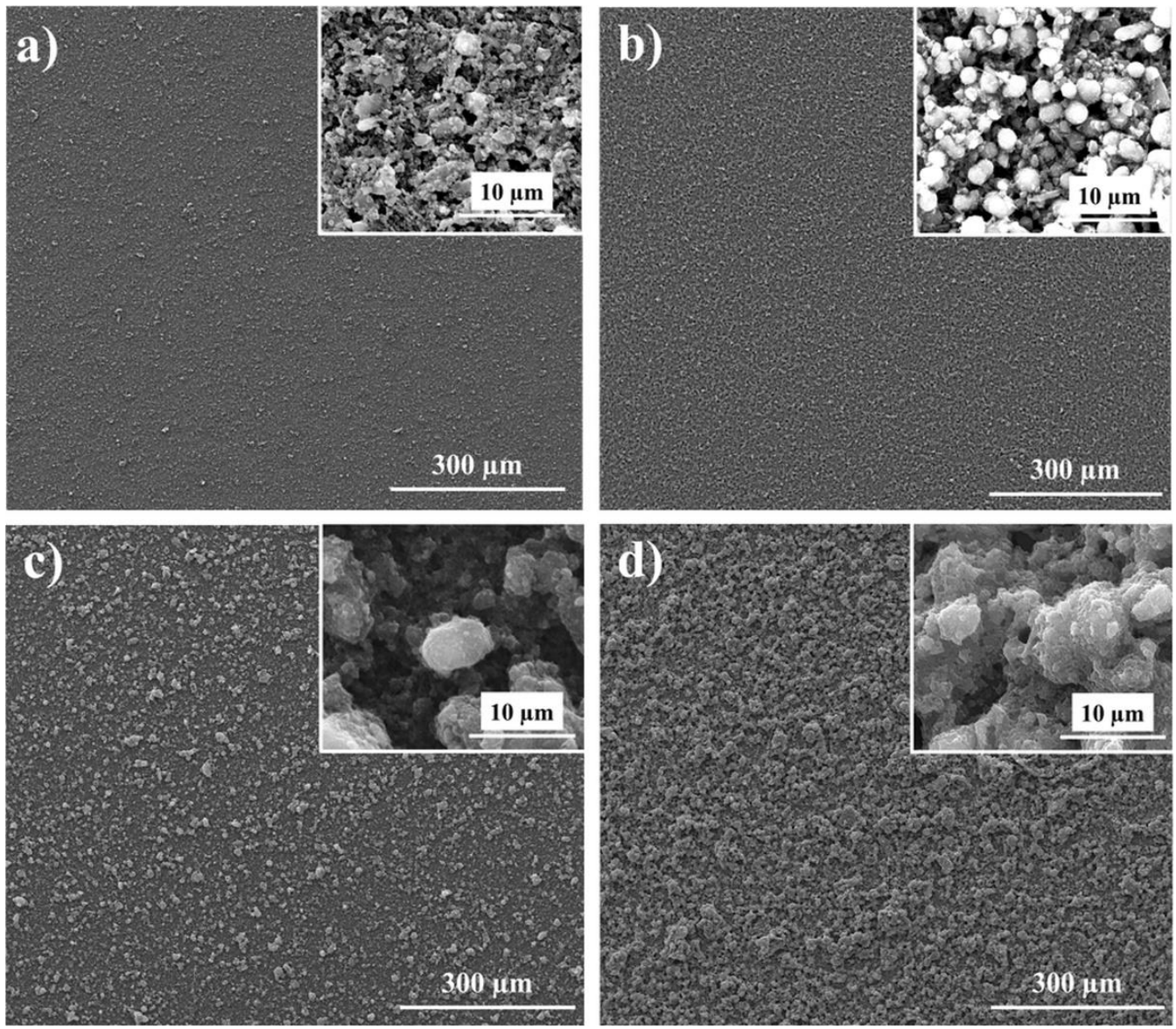

Figure 8. SEM images of the $\mathrm{TiO}_{2}$ photoanodes (a) PhA 1, (b) PhA 2, (c) PhA 3, and (d) PhA4.

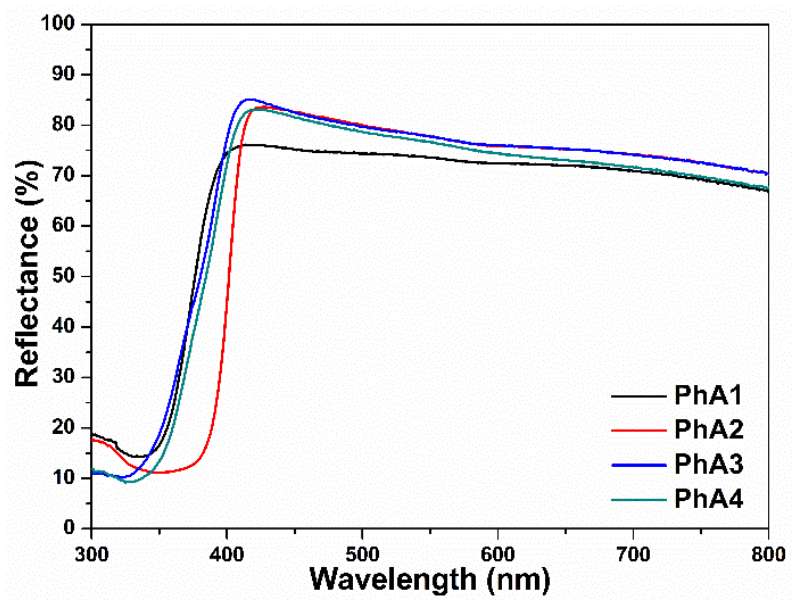

Figure 9. UV-Vis reflectance spectra of the $\mathrm{TiO}_{2}$ photoanodes.

The J-V characteristics of the DSSCs using E and E10\% electrolytes are presented in Figure 10 and the detailed photovoltaic parameters $\left(J_{S C}, V_{O C}, F F\right.$, and $\left.\eta\right)$ for both dyes are summarized in Table 1. In the case of the synthetic dye and E electrolyte, a significant increase in the efficiency is correlated with the addition of the LS2 layer (50\% more), and together with $\mathrm{TiCl}_{4}$ treatment, $136 \%$ is achieved relative to DSSC1. The microsphere rutile structure of $\mathrm{TiO}_{2}$ LS1 had a minor effect on the photovoltaic efficiency caused by the higher light-scattering capacity compared with $\mathrm{TiO}_{2}$ NP. A positive effect of $\mathrm{TiO}_{2}$ LS2 on the photovoltaic parameters is provided by the dendritic morphology presented in the mixture of rutile and anatase polymorphic phases along with the surface hydroperoxo species, 
TiOOH. The increase in $J_{S C}$ (1.5 times) is directly determined by both the rutile phase of the $\mathrm{TiO}_{2} \_\mathrm{LS} 2$ microdendritic structure and the high refractive index $\left(\mathrm{n}_{\text {rutile }}=2.8736\right)$ which reflects the incident sunlight onto the dye, increasing the light-absorbing capacity of the dye. Additionally, the presence of rutile content prompts the electron transfer from rutile to the anatase trapping sites; this synergistic effect inhibits the electron-hole recombination occurrence, thus leading to an increase in DSSC performance [27]. The high anchoring of the dye molecule on the $\mathrm{TiO}_{2}$ surface is due to the hydroxyl group $(-\mathrm{OH})$ given by the $\mathrm{TiOOH}$ surface species and in addition to the $\mathrm{TiCl}_{4}$ treatment have improved the dye loading capacity of the DSSC 4 . Furthermore, the improvement of $\mathrm{V}_{\mathrm{OC}}$ (more than $40 \mathrm{mV}$ ) is the result of the high bandgap energy $(\mathrm{Eg})$ of the $\mathrm{TiO}_{2} \_\mathrm{LS} 2$ compared with the anatase phase (Figure 6) which is only reflected in the most negative conduction band (CB) level, the valence band (VB) level being similar for both crystal phases, rutile and anatase polymorphs. A similar beneficial evolution of the photovoltaic parameters was observed for PhA 4 loaded with the curcumin dye, obtaining a photovoltaic efficiency three times higher than the best efficiency reported for this dye so far [16].

Achieving photovoltaic efficiencies higher than the best efficiency reported so far for both dyes, the complex architecture of PhA4 is validated for the future optimization of the electrolyte, another important component of DSSC.
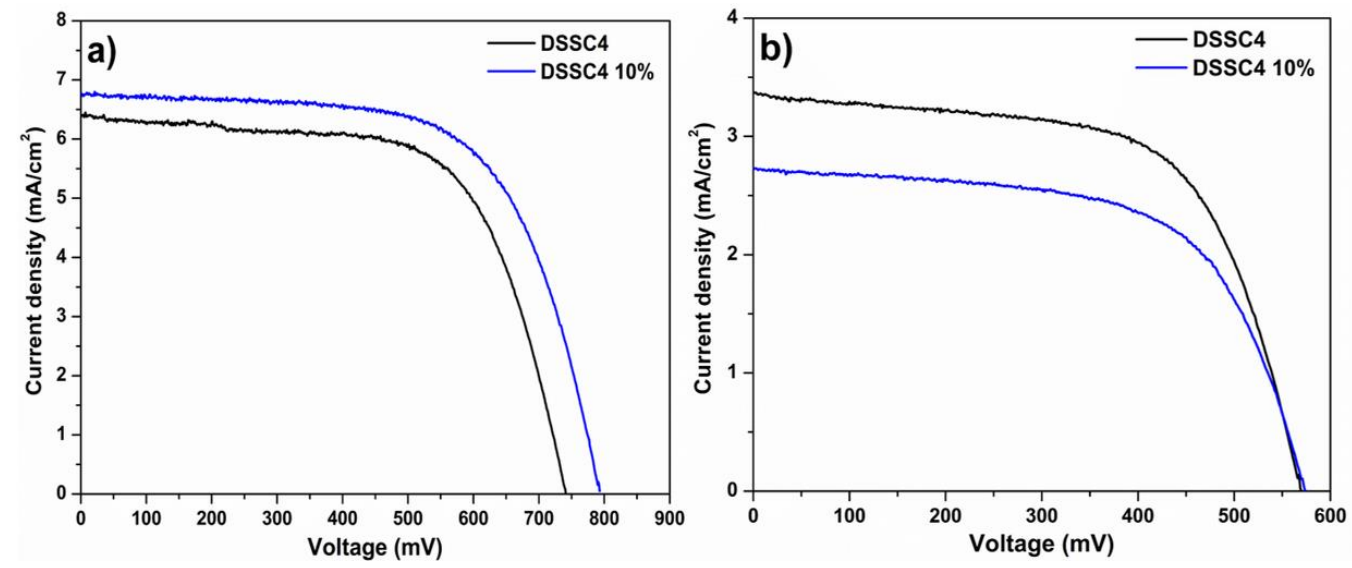

Figure 10. J-V measurements of (a) DN-F01and (b) curcumin-sensitized DSSC4 with E and E10\% electrolytes and under 1 sun $\left(100 \mathrm{~mW} / \mathrm{cm}^{2}\right)$ illumination.

Table 1. Photovoltaic parameters of the DSSCs tested using E and E10\% electrolytes and both synthetic and natural dyes.

\begin{tabular}{|c|c|c|c|c|c|c|}
\hline Sample & Dye & Electrolyte & $\begin{array}{c}J_{S C} \\
(\mathbf{m A})\end{array}$ & $\begin{array}{c}V_{O C} \\
(\mathrm{mV})\end{array}$ & $\begin{array}{c}F F \\
(\%)\end{array}$ & $\begin{array}{c}\eta \\
(\%)\end{array}$ \\
\hline DSSC 1 & \multirow{8}{*}{ DN-F01 } & \multirow{4}{*}{$\mathrm{E}$} & 4.15 & 738 & 42.7 & 1.307 \\
\hline DSSC 2 & & & 4.2 & 743 & 49.7 & 1.550 \\
\hline DSSC 3 & & & 5.76 & 778 & 43.8 & 1.962 \\
\hline DSSC 4 & & & 6.38 & 741 & 65.3 & 3.087 \\
\hline DSSC 1 & & \multirow{4}{*}{$\mathrm{E} 10 \%$} & 4.35 & 726 & 50.0 & 1.579 \\
\hline DSSC 2 & & & 4.32 & 703 & 47.7 & 1.448 \\
\hline DSSC 3 & & & 6.06 & 761 & 50.2 & 2.315 \\
\hline DSSC 4 & & & 6.78 & 792 & 64.7 & 3.474 \\
\hline Best record ${ }^{a}$ & DN-F01 & $\begin{array}{c}\text { 0.6 M TBAI, } 0.1 \mathrm{M} \text { LiI, } 0.05 \mathrm{M} \mathrm{I} 2, \\
\text { and } 0.5 \mathrm{M} \text { 4-tert-butylpyridine } \\
(4-\mathrm{TBP}) \text { in acetonitrile }\end{array}$ & 5.23 & 710 & 64 & 2.39 \\
\hline \multirow{2}{*}{ DSSC 4} & \multirow{2}{*}{ Curcumin } & $\mathrm{E}$ & 3.37 & 570 & 62.9 & 1.208 \\
\hline & & $\mathrm{E} 10 \%$ & 2.73 & 574 & 61.8 & 0.968 \\
\hline Best record $b$ & Curcumin from turmeric powder & $\mathrm{I}^{-} / \mathrm{I}_{3}^{-}$redox based electrolyte & 0.720 & 432 & 40.0 & 0.41 \\
\hline
\end{tabular}

${ }^{a}$ Ref. [15], b Ref. [16]. 
In an attempt to reduce the volatility, toxicity, flammability of the electrolyte, and at the same time, overcome this poor stability on moisture, one of the main steps to eco-friendly materials, the effect of water (Table 1), has been studied in detail for the configuration of DSSC 4. A clear increase in efficiency can be observed with the addition of water in the electrolyte for the DN-F01 dye, which is especially attributable to the increases in $V_{O C}$ with $51 \mathrm{mV}$ by more than in the electrolyte without water. Due to the higher solubility in the water of $\mathrm{I}^{-}$, compared with that of $\mathrm{I}_{3}{ }^{-}$, the addition of water to the electrolyte leads to a positive shift of the potential [28]. If no negative effect of water was observed in the case of the synthetic dye, the curcumin dye was affected and a decrease in the cell photocurrent, mostly due to the dye detachment from the semiconductors surface promoted by the water, was highlighted.

The transmittance spectra (Figure 11) were similar for DSSC 4 , characterized by a high absorption of UV radiation, close to $98 \%$ for DSSC 4 with E10\% electrolyte and a transparency of the DSSCs on the entire PAR domain, in accordance with those reported in the literature [29].
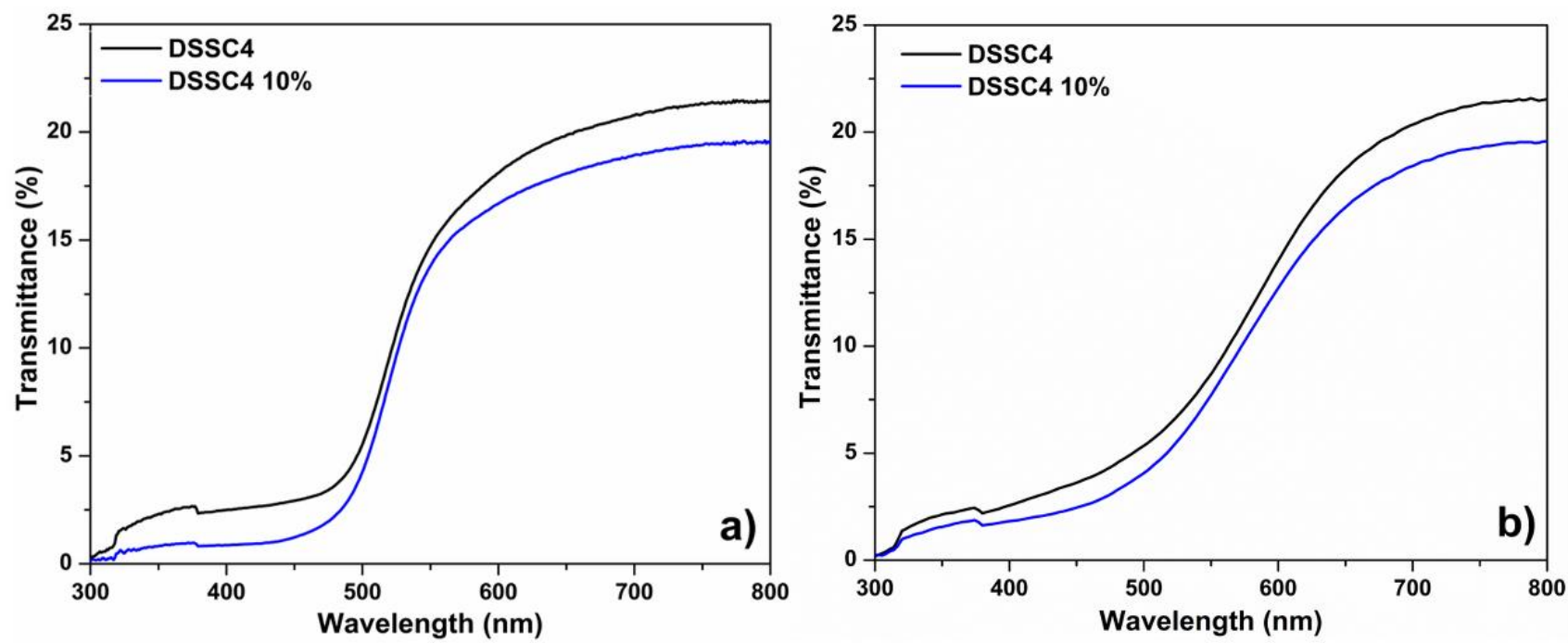

Figure 11. Transmittance spectra of (a) DN-F01and (b) curcumin-sensitized DSSC4 with E and E10\% electrolytes.

One of the most important advantages of the DSSCs is sustainability over the whole year, a prerequisite for successful implementation in a wavelength-selective greenhouse. The effect of different light intensities (ranging from 20 to $100 \mathrm{~mW} / \mathrm{cm}^{2}$ ) on the photovoltaic performance of DSSC 4 was investigated (Table 2, Figures 12 and 13). To give a better understanding of the charge dynamics involved in our DSSCs and the effect of the water, electrochemical impedance spectroscopy (EIS) analysis was performed at $\mathrm{V}_{\mathrm{OC}}$ and under 1 sun illumination. In the equivalent circuit presented in the insets of Figure 14, R1 represents the intrinsic resistance of the assembled cells, $R 2$ is the charge transfer resistance at the $\mathrm{CE} /$ electrolyte interface, and $R 3$ represents the charge transfer resistance at the $\mathrm{TiO}_{2}$ photoelectrode/dye/electrolyte interface. Table 3 summarizes the fitted values of the resistance associated with each interfacial process in the DSSC.

In case of the synthetic dye (Figure 12), under the illumination with different light intensities, the $J_{S C}$ value varies almost identically for both DSSCs, without and with water, from approximately 0.8 to $6.7 \mathrm{~mA} / \mathrm{cm}^{2}$ with a steep increase to $60 \mathrm{~mW} / \mathrm{cm}^{2}$. EIS analysis highlighted that the evolution of $J_{S C}$ is directly correlated with $R 2$ and $R 3$ (Table 3), for example, in the case of $60 \mathrm{~mW} / \mathrm{cm}^{2}$ and $100 \mathrm{~mW} / \mathrm{cm}^{2}$, increasing $J_{S C}$ is determined by reducing the charge transfer resistance at the $\mathrm{TiO}_{2}$ photoelectrode/dye/electrolyte interface and the improved catalytic activity, more drastically for E10\%. The open-circuit potential slightly increases with increasing illumination intensity and becomes almost constant 
after $60 \mathrm{~mW} / \mathrm{cm}^{2}$. The voltage dependence of the output power $(P=I V)$ under different illumination intensities is shown in Figure 12. The power conversion increases with increases in the light intensity until $3087 \mu \mathrm{W}$ for DSSC 4_E and $3474 \mu \mathrm{W}$ for DSSC 4_E10\%, respectively, at $100 \mathrm{~mW} / \mathrm{cm}^{2}$. The stability of our DSSCs with increasing light intensity is highlighted by the near-constant evolution of the fill factor, even with a $10 \%$ water content. DSSC 4_E10 demonstrates nearly 3.5\% photovoltaic efficiency for illumination intensity between $60 \mathrm{~mW} / \mathrm{cm}^{2}$ and $100 \mathrm{~mW} / \mathrm{cm}^{2}$ with a maximum at $60 \mathrm{~mW} / \mathrm{cm}^{2}$.

Table 2. The photovoltaic parameters of DSSC4 under different illumination intensities.

\begin{tabular}{|c|c|c|c|c|c|c|c|c|}
\hline Cell & $P_{\text {in }}\left(\mathrm{mW} / \mathrm{cm}^{2}\right)$ & Electrolyte & Dye & $J_{S C}(\mathbf{m A})$ & $V_{O C}(\mathrm{mV})$ & $P(\mu \mathrm{W})$ & $F F(\%)$ & $\eta(\%)$ \\
\hline \multirow{9}{*}{ DSSC 4} & 20 & \multirow{9}{*}{$\mathrm{E}$} & \multirow{9}{*}{ DN-F01 } & 0.85 & 648 & 387 & 70 & 1.927 \\
\hline & 30 & & & 0.90 & 647 & 409 & 70 & 1.358 \\
\hline & 40 & & & 1.25 & 661 & 579 & 69.7 & 1.439 \\
\hline & 50 & & & 1.46 & 670 & 671 & 68.4 & 1.338 \\
\hline & 60 & & & 3.89 & 729 & 1926 & 67.8 & 3.204 \\
\hline & 70 & & & 4.25 & 728 & 2101 & 67.8 & 2.996 \\
\hline & 80 & & & 5.00 & 732 & 2435 & 66.5 & 3.042 \\
\hline & 90 & & & 5.56 & 736 & 2681 & 65.3 & 2.969 \\
\hline & 100 & & & 6.38 & 741 & 3087 & 65.3 & 3.087 \\
\hline \multirow{9}{*}{ DSSC 4} & 20 & \multirow{9}{*}{ E10\% } & \multirow{9}{*}{ DN-F01 } & 0.80 & 668 & 368 & 68.8 & 1.838 \\
\hline & 30 & & & 0.82 & 659 & 361 & 68.5 & 1.233 \\
\hline & 40 & & & 1.21 & 680 & 564 & 68.2 & 1.402 \\
\hline & 50 & & & 1.43 & 697 & 681 & 68.0 & 1.355 \\
\hline & 60 & & & 4.06 & 768 & 2105 & 67.5 & 3.507 \\
\hline & 70 & & & 4.23 & 771 & 2202 & 67.6 & 3.149 \\
\hline & 80 & & & 4.86 & 776 & 2509 & 66.4 & 3.130 \\
\hline & 90 & & & 5.87 & 786 & 3032 & 65.6 & 3.362 \\
\hline & 100 & & & 6.78 & 792 & 3474 & 64.7 & 3.474 \\
\hline \multirow{9}{*}{ DSSC 4} & 20 & \multirow{9}{*}{$\mathrm{E}$} & \multirow{9}{*}{ Curcumin } & 0.56 & 529 & 426 & 64.4 & 0.953 \\
\hline & 30 & & & 0.60 & 532 & 213 & 67.0 & 0.713 \\
\hline & 40 & & & 0.80 & 537 & 291 & 67.6 & 0.726 \\
\hline & 50 & & & 0.87 & 537 & 313 & 66.9 & 0.625 \\
\hline & 60 & & & 2.05 & 570 & 747 & 64.0 & 1.246 \\
\hline & 70 & & & 2.06 & 564 & 765 & 65.8 & 1.092 \\
\hline & 80 & & & 2.43 & 565 & 859 & 62.6 & 1.074 \\
\hline & 90 & & & 2.72 & 567 & 1004 & 65.2 & 1.117 \\
\hline & 100 & & & 3.37 & 570 & 1208 & 62.9 & 1.208 \\
\hline \multirow{9}{*}{ DSSC 4} & 20 & \multirow{9}{*}{ E10\% } & \multirow{9}{*}{ Curcumin } & 0.38 & 537 & 125 & 60.7 & 0.619 \\
\hline & 30 & & & 0.43 & 532 & 149 & 64.7 & 0.493 \\
\hline & 40 & & & 0.64 & 538 & 220 & 64.0 & 0.551 \\
\hline & 50 & & & 0.68 & 539 & 239 & 64.9 & 0.476 \\
\hline & 60 & & & 1.65 & 560 & 581 & 62.8 & 0.967 \\
\hline & 70 & & & 1.88 & 568 & 672 & 62.8 & 0.958 \\
\hline & 80 & & & 2.04 & 567 & 732 & 63.1 & 0.912 \\
\hline & 90 & & & 2.35 & 569 & 852 & 63.7 & 0.946 \\
\hline & 100 & & & 2.73 & 574 & 969 & 61.8 & 0.968 \\
\hline
\end{tabular}

In the case of the curcumin dye (Figure 13), although the evolution of the photovoltaic parameters $\left(J_{S C}, V_{O C}, f f, \eta\right)$ depending on the illumination intensity is similar to that of the synthetic dye, the water slightly affects the performance of the DSSC (increasing R2 and $R 3$ ), but not the stability under illumination. The photovoltaic efficiency remains almost constant for illumination intensities between $60 \mathrm{~mW} / \mathrm{cm}^{2}$ and $100 \mathrm{~mW} / \mathrm{cm}^{2}$ with a maximum at $60 \mathrm{~mW} / \mathrm{cm}^{2}$.

Our water-based dye-sensitized solar cells loaded with synthetic and natural UV dyes have revealed excellent performance even under conditions of not-optimal lighting, which 
can usually occur in real outdoor applications, such as a greenhouse during of the day, month, or season.

Table 3. EIS parameters obtained from fitting the Nyquist plots of DSSC 4 with and without water content using both DN-F01 and curcumin dye, and under $60 \mathrm{~mW} / \mathrm{cm}^{2}$ and $100 \mathrm{~mW} / \mathrm{cm}^{2}$ of the illumination intensity.

\begin{tabular}{|c|c|c|c|c|c|c|}
\hline Cell & Dye & $\operatorname{Pin}\left(\mathrm{mW} / \mathrm{cm}^{2}\right)$ & Electrolyte & $R 1(\Omega)$ & $R 2(\Omega)$ & $R 3(\Omega)$ \\
\hline \multirow{8}{*}{ DSSC 4} & \multirow{4}{*}{ DN-F01 } & 60 & \multirow{2}{*}{ E } & 7.15 & 3.2 & 12.4 \\
\hline & & 100 & & 7.14 & 2.26 & 7.56 \\
\hline & & 60 & \multirow{2}{*}{ E10\% } & 6.82 & 1.64 & 14.51 \\
\hline & & 100 & & 6.82 & 1.27 & 8.27 \\
\hline & \multirow{4}{*}{ Curcumin } & 60 & \multirow{2}{*}{ E } & 7.09 & 3.08 & 21.24 \\
\hline & & 100 & & 7.09 & 2.14 & 13.24 \\
\hline & & 60 & \multirow{2}{*}{ E10\% } & 7.65 & 3.79 & 32.96 \\
\hline & & 100 & & 7.8 & 2.51 & 14.67 \\
\hline
\end{tabular}
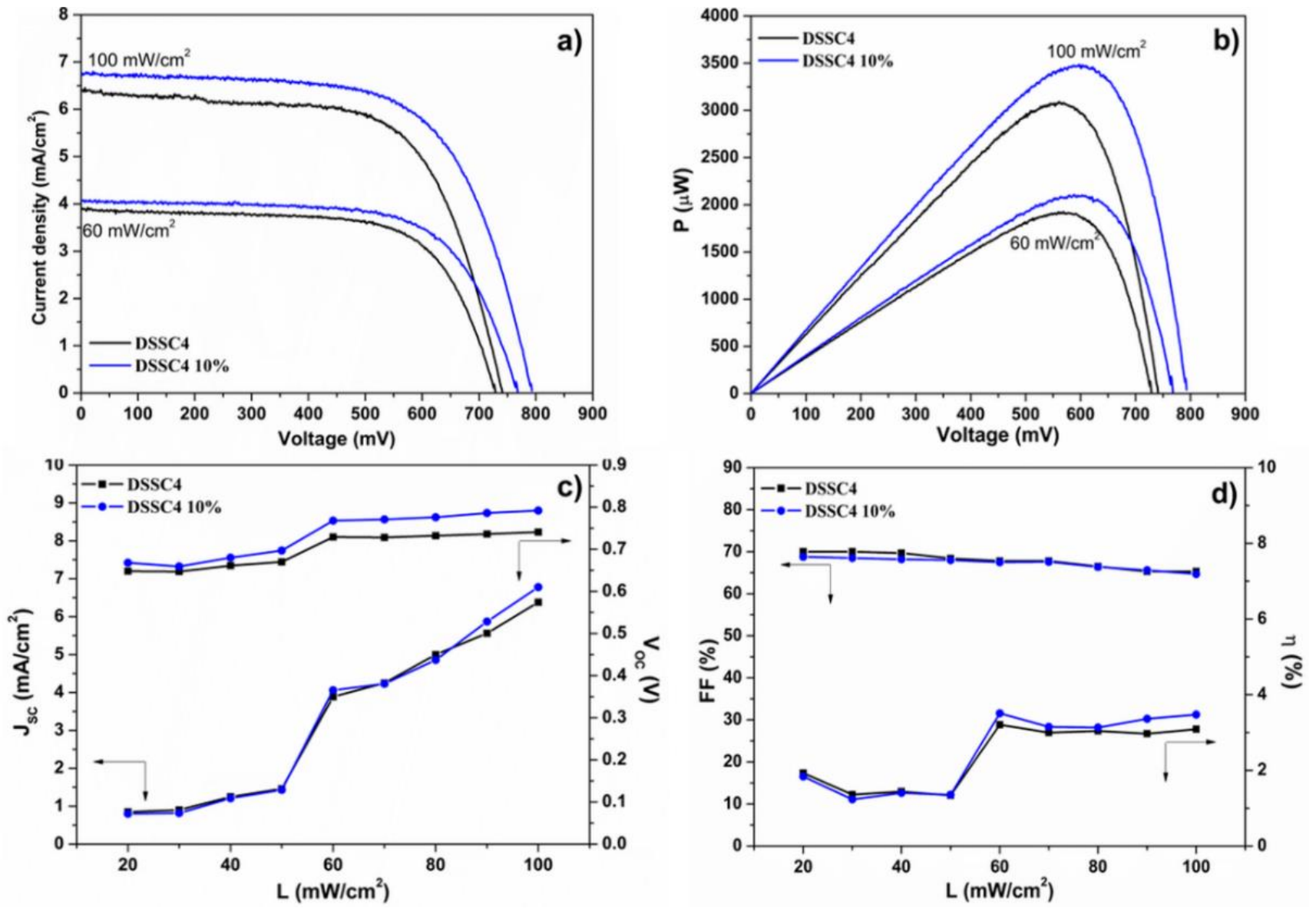

Figure 12. The photovoltaic performance of DN-F01 sensitized DSSC4 under different illumination intensities tested using $\mathrm{E}$ and E10\% electrolytes: (a) J-V characteristics; (b) voltage dependence of the calculated power $\mathrm{P}$; (c) dependence of $V_{O C}$ and $J_{S C}$ on the illumination intensity; (d) dependence of efficiency and fill factor on the illumination intensity. 

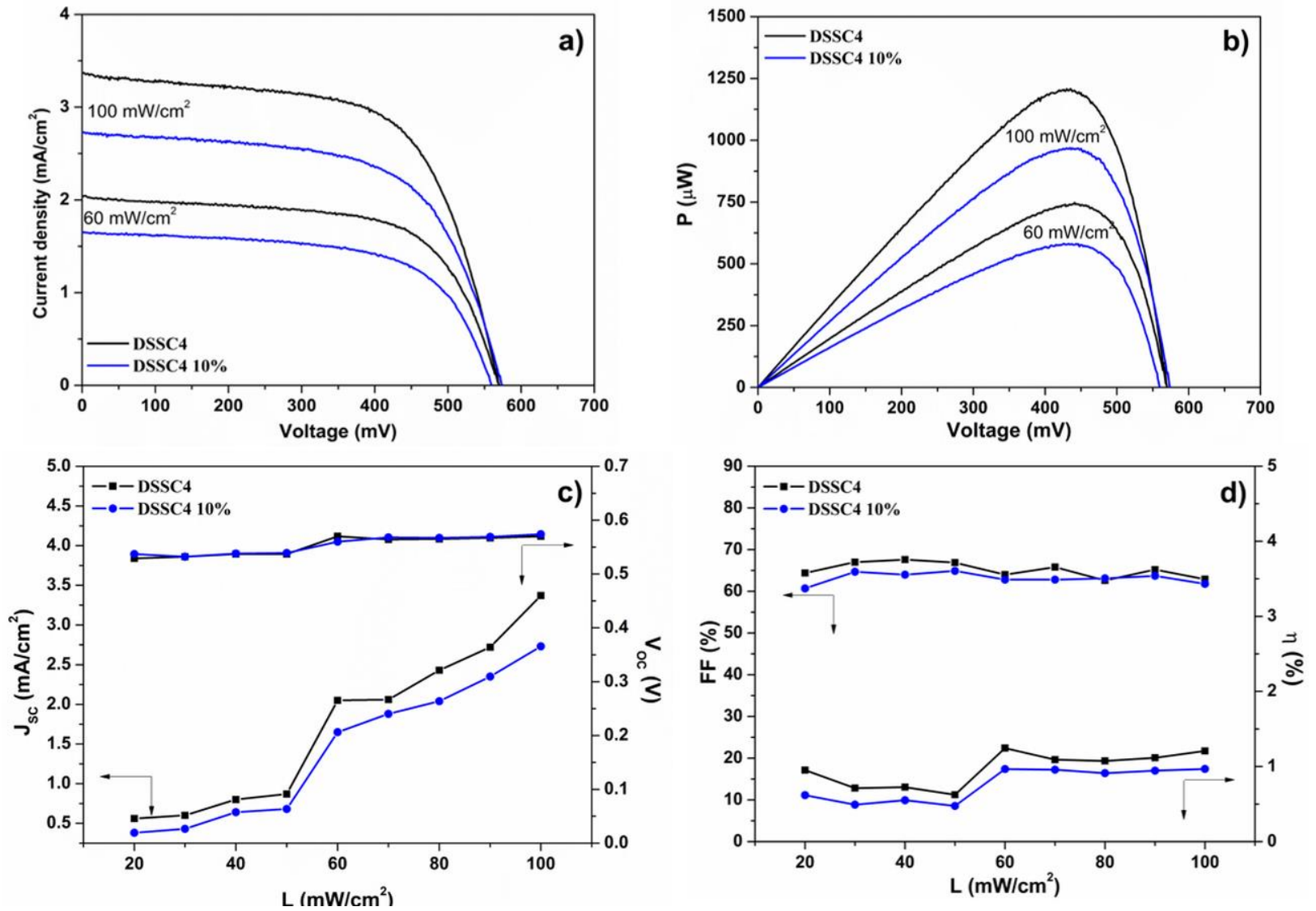

Figure 13. The photovoltaic performance of curcumin sensitized DSSC4 under different illumination intensities tested using E and E10\% electrolytes: (a) J-V characteristics; (b) voltage dependence of the calculated power $\mathrm{P}$; (c) dependence of $V_{O C}$ and $J_{S C}$ on the illumination intensity; (d) dependence of efficiency and fill factor on the illumination intensity.
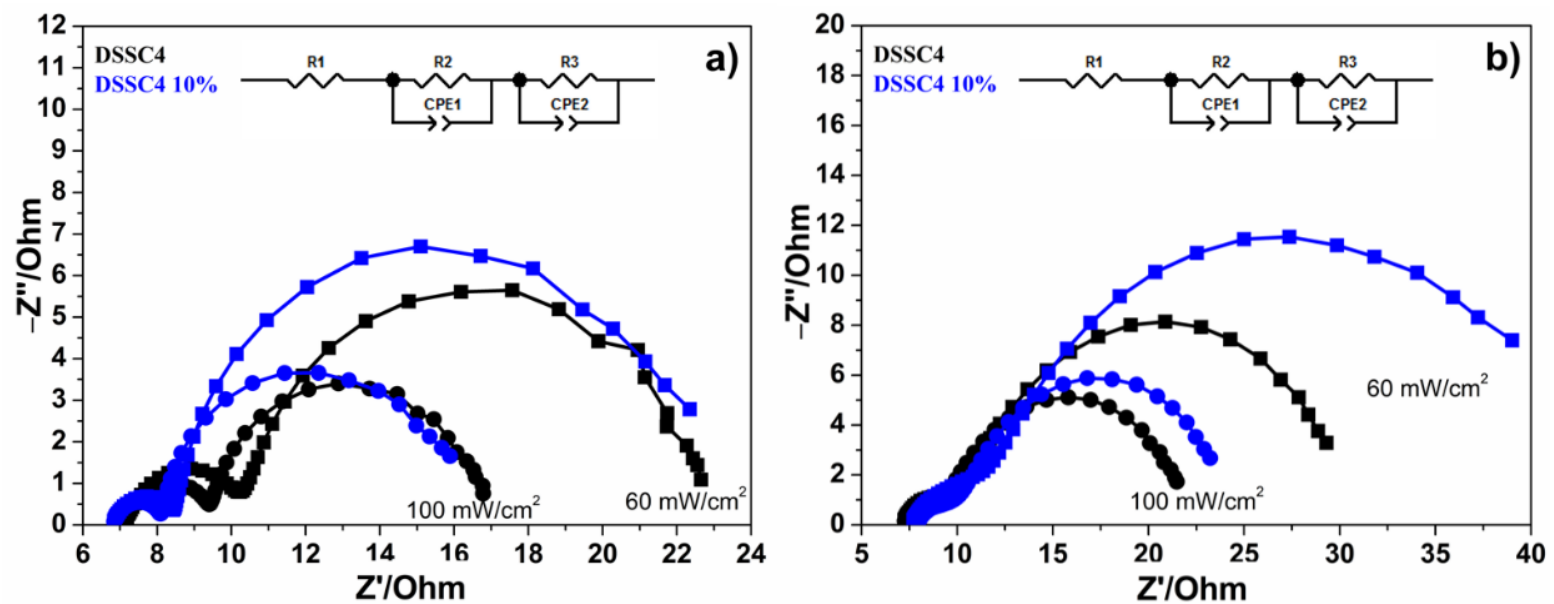

Figure 14. Impedance spectra of (a) DN-F01and (b) curcumin sensitized DSSC4 with E and E10\% electrolytes under $60 \mathrm{~mW} / \mathrm{cm}^{2}$ and $100 \mathrm{~mW} / \mathrm{cm}^{2}$ of the illumination intensity. The inset shows the equivalent circuit diagram used to fit the observed impedance spectra.

\section{Conclusions}

In conclusion, a photoanode with a complex architecture consisting of a $\mathrm{TiO}_{2} \_\mathrm{NP}$ layer, a $\mathrm{TiO}_{2} \_$LS2 layer, and $\mathrm{TiCl}_{4}$ treatment was designed, built, and optimized for loading with an affordable commercial UV synthetic and natural dye using a water-based electrolyte. 
The best water-based dye-sensitized solar cell has demonstrated nearly $3.5 \%$ of photovoltaic efficiency at an illumination intensity between $60 \mathrm{~mW} / \mathrm{cm}^{2}$ and $100 \mathrm{~mW} / \mathrm{cm}^{2}$. Highlighting the maximum efficiency during all four seasons, along with selective absorption of UV, transparent PAR, and improved eco-friendly characteristics of the materials used, has demonstrated experimentally that the implementation of water-based dye-sensitized solar cells in a wavelength-selective and autonomous greenhouses is a viable and inexpensive concept for an agrivoltaic system.

Author Contributions: Conceptualization, M.M.; methodology, M.V., D.U. and D.A.; validation, M.M., L.-M.R. and S.N.; formal analysis, M.V., D.U. and D.A.; investigation, M.V., D.U. and D.A.; writing-original draft preparation, M.M., M.V. and D.A.; writing-review and editing, M.M. and D.U.; supervision, M.M. All authors have read and agreed to the published version of the manuscript.

Funding: This research was funded by a grant from the Romanian National Authority for Scientific Research and Innovation, UEFISCDI Project No. PN-III-P2-2.1-PED-2019-2091, PNCDI III.

Institutional Review Board Statement: Not applicable.

Informed Consent Statement: Not applicable.

Data Availability Statement: The datasets used and/or analyzed during the current study are available from the corresponding author on reasonable request.

Conflicts of Interest: The authors declare no conflict of interest.

\section{References}

1. Dominguez, A.; Kleissl, J.; Luvall, J.C. Effects of solar photovoltaic panels on roof heat transfer. Sol. Energy 2011, 85, 2244-2255. [CrossRef]

2. Snaith, H.J. Estimating the maximum attainable efficiency in dye sensitized solar cells. Adv. Funct. Mater. 2010, 20 , 13-19. [CrossRef]

3. Vajda, M.; Ursu, D.; Mosoarca, C.; Duteanu, N.; Miclau, M. Experimental investigation of hydrogen insertion in copper oxide on photovoltaic performance of p-type dye-sensitized solar cell. Int. J. Energy Res. 2020, 45, 5309-5317. [CrossRef]

4. Vajda, M.; Ursu, D.; Duteanu, N.; Miclau, M. Low lying valence band edge materials based on copper oxide for tandem dye-sensitized solar cells. Mater. Lett. 2020, 275, 128151. [CrossRef]

5. Albulescu, D.; Ursu, D.; Dabici, A.; Birdeanu, M.; Duteanu, N.; Popa, S.; Miclau, M.; Nitu, S. Impact of the selectivity of titanium dioxide on photovoltaic performance of anthocyanin-sensitized solar cells. Energy Sources Part A Recovery Util. Environ. Eff. 2021, 1-15. [CrossRef]

6. Wang, Y.C.; Wang, D.Y.; Jiang, Y.T.; Chen, H.A.; Chen, C.C.; Ho, K.C.; Chou, H.L.; Chen, C.W. FeS 2 nanocrystal ink as a catalytic electrode for dye-sensitized solar cells. Angew. Chem. Int. Ed. Engl. 2013, 52, 6694-6698. [CrossRef]

7. Xu, S.; Luo, Y.; Liu, G.; Qiao, G.; Zhong, W.; Xiao, Z.; Luo, Y.; Ou, H. Bifacial dye-sensitized solar cells using highly transparent PEDOT:PSS films as counter electrodes. Electrochim. Acta 2015, 156, 20-28. [CrossRef]

8. Lu, L.; Ya'acob, M.E.; Anuar, M.S.; Chen, G.; Othman, M.H.; Noor Iskandar, A.; Roslan, N. Thermal analysis of a portable DSSC mini greenhouse for botanical drugs cultivation. Energy Rep. 2020, 6, 238-253. [CrossRef]

9. Ntinas, G.K.; Kadoglidou, K.; Tsivelika, N.; Krommydas, K.; Kalivas, A.; Ralli, P.; Irakli, M. Performance and hydroponic tomato crop quality characteristics in a novel greenhouse using dye-sensitized solar cell technology for covering material. Horticulturae 2019, 5, 42. [CrossRef]

10. Bhattacharya, S.; Datta, J. Wide-low energy coupled semi-conductor layers of $\mathrm{TiO}_{2}-\mathrm{CdX}$ boosting the performance of DSSC. Sol. Energy 2020, 208, 674-687. [CrossRef]

11. Sakthivel, T.; Ashok Kumar, K.; Ramanathan, R.; Senthilselvan, J.; Jagannathan, K. Silver doped $\mathrm{TiO}_{2}$ nano crystallites for dye-sensitized solar cell (DSSC) applications. Mater. Res. Express 2017, 4, 126310. [CrossRef]

12. Wang, Y.C.; Li, S.S.; Wen, C.Y.; Chen, L.Y.; Ho, K.C.; Chen, C.W. Dual functional polymer interlayer for facilitating ion transport and reducing charge recombination in dye-sensitized solar cells. ACS Appl. Mater. Interfaces 2016, 8, 33666-33672. [CrossRef] [PubMed]

13. Raviv, M.; Antignus, Y. UV radiation effects on pathogens and insect pests of greenhouse-grown crops. Photo-Chem. Photobiol. 2004, 79, 219-226. [CrossRef] [PubMed]

14. Galliano, S.; Bella, F.; Gerbaldi, C.; Falco, M.; Viscardi, G.; Grätzel, M.; Barolo, C. Photoanode/Electrolyte interface stability in aqueous dye-sensitized solar cells. Energy Technol. 2017, 5, 300-311. [CrossRef]

15. Marinado, T.; Nonomura, K.; Nissfolk, J.; Karlsson, M.K.; Hagberg, D.P.; Sun, L.; Mori, S.; Hagfeldt, A. How the nature of Triphenylamine-Polyene dyes in dye-sensitized solar cells affects the open-circuit voltage and electron lifetimes. Langmuir 2010, 26, 2592-2598. [CrossRef] [PubMed] 
16. Jasim, K.E.; Cassidy, S.; Henari, F.Z.; Dakhel, A.A. Curcumin dye-sensitized solar cell. J. Energy Power Eng. 2017, 11, 409-416. [CrossRef]

17. Ursu, D.; Vajda, M.; Miclau, M. Investigation of the p-type dye-sensitized solar cell based on full Cu $\mathrm{Cu}_{2} \mathrm{O}$ electrodes. J. Alloy. Compd. 2019, 802, 86-92. [CrossRef]

18. Muniz, F.T.; Miranda, M.A.; Morilla Dos Santos, C.; Sasaki, J.M. The Scherrer equation and the dynamical theory of X-ray diffraction. Acta Cryst. A Found Adv. 2016, 72, 385-390. [CrossRef]

19. Praveen, P.; Viruthagiri, G.; Mugundan, S.; Shanmugam, N. Structural, optical and morphological analyses of pristine titanium di-oxide nanoparticles-synthesized via sol-gel route. Spectrochim. Acta A Mol. Biomol. Spectrosc. 2014, 117, 622-629. [CrossRef]

20. El-Sherbiny, S.; Morsy, F.; Samir, M.; Fouad, O.A. Synthesis, characterization and application of $\mathrm{TiO}_{2}$ nanopowders as special paper coating pigment. Appl. Nanosci. 2013, 4, 305-313. [CrossRef]

21. Kadam, A.N.; Dhabbe, R.S.; Kokate, M.R.; Gaikwad, Y.B.; Garadkar, K.M. Preparation of N doped TiO 2 via microwave-assisted method and its photocatalytic activity for degradation of Malathion. Spectrochim. Acta A Mol. Biomol. Spectrosc. 2014, 133, 669-676. [CrossRef]

22. Yurdakal, S.; Çetinkaya, S.; Augugliaro, V.; Palmisano, G.; Soria, J.; Sanz, J.; Torralvo, M.J.; Livraghi, S.; Giamello, E.; Garlisi, C. Alkaline treatment as a means to boost the activity of $\mathrm{TiO}_{2}$ in selective photocatalytic processes. Catal. Sci. Technol. 2020, 10, 5000-5012. [CrossRef]

23. Makula, P.; Pacia, M.; Macyk, W. How to correctly determine the band gap energy of modified semiconductor photocatalysts based on UV-Vis spectra. J. Phys. Chem. Lett. 2018, 9, 6814-6817. [CrossRef]

24. Nikolskaia, A.; Vildanova, M.; Kozlov, S.; Tsvetkov, N.; Larina, L.; Shevaleevskiy, O. Charge transfer in mixed-phase TiO 2 Photoelectrodes for Perovskite solar cells. Sustainability 2020, 12, 788. [CrossRef]

25. Castrejón-Sánchez, V.; López, R.; Ramón-González, M.; Enríquez-Pérez, Á.; Camacho-López, M.; Villa-Sánchez, G. Annealing control on the anatase/rutile ratio of nanostructured titanium dioxide obtained by sol-gel. Crystals 2018, 9, 22. [CrossRef]

26. Liu, Z.; Su, X.; Hou, G.; Bi, S.; Xiao, Z.; Jia, H. Spherical $\mathrm{TiO}_{2}$ aggregates with different building units for dye-sensitized solar cells. Nanoscale 2013, 5, 8177-8183. [CrossRef]

27. Fan, Y.H.; Ho, C.Y.; Chang, Y.J. Enhancement of dye-sensitized solar cells efficiency using mixed-phase $\mathrm{TiO}_{2}$ nanoparticles as photoanode. Scanning 2017, 2017, 9152973. [CrossRef] [PubMed]

28. Law, C.; Pathirana, S.C.; Li, X.; Anderson, A.Y.; Barnes, P.R.; Listorti, A.; Ghaddar, T.H.; O’Regan, B.C. Water-based electrolytes for dye-sensitized solar cells. Adv. Mater. 2010, 22, 4505-4509. [CrossRef] [PubMed]

29. Nogueira, A.F. Shades of transparency. Nat. Energy 2020, 5, 428-429. [CrossRef] 